\title{
Documentation of traditional knowledge of herbal plant in Kalvarayan Hills, Vallupuram District, Tamil Nadu
}

\author{
J. Nithyadevi, R. Sivakumar \\ Department of Botany, Annamalai University, Annamalai Nagar, Tamil Nadu, India \\ *E-mail address: herbnithi@gmail.com
}

\begin{abstract}
The study was carried out to assess the traditional knowledge of herbal plants in a Kalvarayan Hills, Villupuram District, Tamil Nadu. It was carried out through face to face interview with respondent, collection and identification of herbal plants in the hills. A total number of 60 species of herbal plants were recorded during a series of folk botanical surveys at a hill at Villupuram District, Tamil Nadu. A majority of these species are herbaceous angiosperms, followed by trees and shrubs. The most common part of the plant used in preparing for herbal medicine is the bark, leaves, roots, stem, flowers, and fruits. Mostly the plants are used for general health, to treat dermatological complaints, reproductive system, abdominal problems and fever compared to other ailments. The most common method of herbal preparation is poultice, followed by decoction and infusion. Thus, more medicinal plants are used topically than orally.
\end{abstract}

Keywords: Traditional knowledge; Herbal Medicine; Kalvarayan Hills

\section{INTRODUCTION}

Documentation of traditional knowledge on medicinal plants is still carried out in many parts of the world. The main aims for such efforts to continue are poor transmission of the knowledge edge to younger generations, the potential use this knowledge in the exploitation of plants of pharmaceutical industries, and the need to conserve rare or highly demanded plants species in traditional medicine. Ayyanar and Ignacimuthu (2005) conducted an ethno botanical survey among ethnic groups in southern Western Ghuts of India. The investigation showed that the tribes of the region used 20 species of medicinal plants. Medicines were prepared in the form of powder, decoction, paste and a town in Ethiopia. Ethnomedicobotany is one of the tools that help to deal with the direct relationship of plants and man to prevent and cure ailments. Alcorn, (1981), Jain, (1986).

India is known for rich source of biological wealth having more than 17, 500 wild plant species, and of these 4,000 species have medicinal values Sharma, (1997). Use of plant as medicine is not of recent origin, 1,200 herbal plants are mentioned in ancient India texts Jain and Mudgal, (1999). Even today, $80 \%$ of the world's population relies on traditional plant medicine as also Indian by various rural and tribal communities through Indian system 
of medicine and other undocumented traditional practices Khan et al., (2004), Gadgil (1996), Mashelkar, (2002).

Herbal plants used for the preparation of Ayurvedic, Unani, Sidha and homeopathic medicine are available in different climatic zones of the state Rama Shankar et al., (1994) Rama Shankar et al., (1995), Rawat, (1996), Rama Shankar and Rawat, (2002). Due to various physical barriers they have been leading practically a life of seclusion thereby preserving their traditional knowledge intact Haridasan. K (2001). So, an attempt has been made to document traditional knowledge on medicinal plants in Kalrayan Hills.

\section{MATERIAL AND METHODS}

A folk botanical survey of medicinal plants was carried out in Kalrayan Hills, Tamil Nadu. The hills located in the Eastern Ghats of the southern Indian state of Tamil Nadu. Along with the Pachaimalai, Javadi, and Shevaroy hills, they separate the Kaveri River basin to the south from the Palar River basin to the north. The hills range in height from 2000 feet to 3000 feet and extend over an area of 1095 square kilometers. It straddle a number of Tamil Nadu districts, extending northeast from the Salem District.

The range serves as a boundary between the Salem and Villupuram districts. The tribals are divided into two sections, the northern section, referred to as the Chinna ("little") Kalrayans, and the southern section, called the Periya ("big") Kalrayans. The Chinna Kalrayans average 2700 feet in height, while the Periya Kalrayans average 4000 feet. The range as a whole is fairly smooth, with soil well-suited for plant growth. Scrub jungles reach up to 400 meters' in altitude, while deciduous forests can be found between above 800 meters'. Sholas, a type of high-altitude stunted evergreen forest, can be found growing on isolated plateaus.

Though the forest stand is growing, due to "habitat uniqueness, human impacts and cultural tradition," conservation efforts are needed. The tribals still practice herbal medicine based mainly on plants that grow naturally in the surrounding habitats and also cultivated plants. Traditional knowledge of medicinal plants in the study site is still based on memory of what they have learned from kalrayans. It is thus very important to record this traditional knowledge. Information was obtained through observation, participation and face to face interviews with adult villagers, local healers and herbalists during each visit using the method of ethno-botanical enquiry.

The ages of the informants range from about 45 years to 70 years. The parts of the plants used to treat diseases, types of diseases treated, doses and method of administration were carefully recorded in the field. The villagers were mostly willing to share their traditional knowledge on herbal medicine.

\section{RESULT AND DISCUSSION} kalrayans.

In our survey we recorded 20 plant species used in traditional medicine by the 
Table1. Shown the records of the plants binomial name, common name, family name, parts used and disease for administration.

\begin{tabular}{|c|c|c|c|c|}
\hline S.NO. & PLANT NAME & $\begin{array}{l}\text { PARTS } \\
\text { USED }\end{array}$ & AILMENT & MODE OF APPLICATION \\
\hline 1. & $\begin{array}{l}\text { Aerva lanata Linn. } \\
\text { Amaranthaceae } \\
\text { Sirukanpeelai }\end{array}$ & $\begin{array}{l}\text { Whole } \\
\text { plants }\end{array}$ & $\begin{array}{l}\text { Vermifuge and } \\
\text { suppurative } \\
\text { diuretic }\end{array}$ & $\begin{array}{l}\text { Leaf paste is applied to the } \\
\text { injuries. Vermifuge and } \\
\text { suppurative diuretic }\end{array}$ \\
\hline 2. & $\begin{array}{l}\text { Achyranthus aspera } L . \\
\text { Amaranthaceae } \\
\text { Naiuruvi }\end{array}$ & $\begin{array}{l}\text { Whole } \\
\text { plants }\end{array}$ & $\begin{array}{l}\text { Rabies, piles clean } \\
\text { teeth. }\end{array}$ & $\begin{array}{l}\text { The boiled leaves are } \\
\text { consumed to relieve internal } \\
\text { piles and rabies. And roots } \\
\text { are used as a brush to relieve } \\
\text { pain and clean teeth.. }\end{array}$ \\
\hline 3. & $\begin{array}{l}\text { Andrographis paniculata } \\
\text { Neex. } \\
\text { Acanthaceae } \\
\text { Pambukaipachilai }\end{array}$ & Leaves & Snake bites & $\begin{array}{l}\text { Crushed leaves mixed in the } \\
\text { warm water are administered } \\
\text { for the treatment of malaria } \\
\text { and cough. A handful of } \\
\text { leaves are taken and an } \\
\text { extract is made, mixed with } \\
\text { milk, is taken internally to } \\
\text { cure snake bites. }\end{array}$ \\
\hline 4. & $\begin{array}{l}\text { Amaranthus spinosus } L . \\
\text { Amaranthaceae } \\
\text { Mullukeerai }\end{array}$ & $\begin{array}{l}\text { Whole } \\
\text { plants }\end{array}$ & Gout & $\begin{array}{l}\text { Plant paste mixed with deer } \\
\text { musk is applied for the } \\
\text { treatment of gout. }\end{array}$ \\
\hline 5. & $\begin{array}{l}\text { Aristolochia indica L. } \\
\text { Aristolochaceae } \\
\text { Aaduthinnapalai }\end{array}$ & Roots & Antidote & $\begin{array}{l}\text { Dried root are powdered and } \\
\text { about } 10 \mathrm{~g} \text { of powder is given } \\
\text { with } 100 \mathrm{ml} \text { of human urine } \\
\text { as the antidote for snake } \\
\text { bites. }\end{array}$ \\
\hline 6. & $\begin{array}{l}\text { Boerhaavia diffusa L. } \\
\text { Nictaginaceae } \\
\text { Mookirattai }\end{array}$ & Roots & $\begin{array}{l}\text { Diuretic, anti } \\
\text { inflammatory anti } \\
\text { bacterial } \\
\text { anthelmintic } \\
\text { flatulence, colic \& } \\
\text { skin disease. }\end{array}$ & $\begin{array}{l}\text { Whole plant decoction is } \\
\text { taken. Fruits are consumed } \\
\text { at flatulence, colic \&skin } \\
\text { disease. }\end{array}$ \\
\hline 7. & $\begin{array}{l}\text { Acalypha indica } L . \\
\text { Euphobiaceae } \\
\text { Kuppaimeni }\end{array}$ & Leaves & $\begin{array}{l}\text { Skin disease, } \\
\text { dysentery, and } \\
\text { diarrhea }\end{array}$ & $\begin{array}{l}\text { Root decoction are taken } \\
\text { orally administered } 100 \mathrm{~g} \text { per } \\
\text { day for one day used to } \\
\text { dysentery. Leaves are used to } \\
\text { cure the skin disease. }\end{array}$ \\
\hline 8. & $\begin{array}{l}\text { Cathranthus } \\
\text { L.(G.Don.) } \\
\text { Apocynaceae } \\
\text { Nithiyakalyani }\end{array}$ & $\begin{array}{l}\text { Whole } \\
\text { plants }\end{array}$ & Diabetes & $\begin{array}{l}\text { Whole plant is powdered and } \\
\text { mixed with cow's milk and } \\
\text { taken orally to treat diabetes. } \\
\text { The paste is whole plant is } \\
\text { taken for improving the } \\
\text { digestion and inducing } \\
\text { appetite. }\end{array}$ \\
\hline 9. & $\begin{array}{l}\text { Datura metal } L . \\
\text { Solanaceae } \\
\text { Umatthai }\end{array}$ & $\begin{array}{l}\text { Leaves and } \\
\text { fruits }\end{array}$ & $\begin{array}{l}\text { Asthma wheezing } \\
\text { problem, fire burn } \\
\text { wound }\end{array}$ & $\begin{array}{l}\text { Leaf paste is externally } \\
\text { applied on the burn wound to } \\
\text { cure skin. Few drops of leaf } \\
\text { juice is poured into ear to } \\
\text { treat earache Leaves and fruit } \\
\text { are used for to treat asthma } \\
\text { or wheezing like problems. }\end{array}$ \\
\hline 10. & $\begin{array}{l}\text { Eclipta alba } L . \\
\text { Asteraceae } \\
\text { Karsalankanni }\end{array}$ & $\begin{array}{l}\text { Whole } \\
\text { plants }\end{array}$ & Dandruff & $\begin{array}{l}\text { The leaf extract is applied to } \\
\text { relieve the dandruff and } \\
\text { blacken gray hair. }\end{array}$ \\
\hline 11. & $\begin{array}{l}\text { Leucas aspera } L . \\
\text { Lamiaceae } \\
\text { Thumbai }\end{array}$ & $\begin{array}{l}\text { Leaves and } \\
\text { flowers }\end{array}$ & Cough and cold & $\begin{array}{l}\text { The vaporous from boiled } \\
\text { leaves are inhaled to relieve } \\
\text { cough and cold. }\end{array}$ \\
\hline
\end{tabular}




\begin{tabular}{|c|c|c|c|c|}
\hline 12. & $\begin{array}{l}\text { Ocimum sactum } L . \\
\text { Lamiaceae } \\
\text { Tulasi }\end{array}$ & Leaves & Whooping cough & $\begin{array}{l}\text { Leaves juice is used in cold, } \\
\text { fever and diabetes. }\end{array}$ \\
\hline 13. & $\begin{array}{l}\text { Phyllanthus niruri } L . \\
\text { Euphorbiaceae } \\
\text { Keezhanelli }\end{array}$ & $\begin{array}{l}\text { Whole } \\
\text { plants }\end{array}$ & $\begin{array}{l}\text { Diabetes, } \\
\text { hypertension, pain } \\
\text { during menses } \\
\text { and jaundice. }\end{array}$ & $\begin{array}{l}\text { Root Decoction is taken orally } \\
\text { administered ( } 50 \mathrm{~g} \text { ) per day } \\
\text { for scorpion sting day. }\end{array}$ \\
\hline 14. & $\begin{array}{l}\text { Rauvolfia serpentine Benth. } \\
\text { Et.Kurz. } \\
\text { Apocynaceae } \\
\text { Pambukadiver }\end{array}$ & Roots & $\begin{array}{l}\text { Antidote for snake } \\
\text { bites and scorpion } \\
\text { sting. }\end{array}$ & $\begin{array}{l}\text { Roots are chewed for stomach } \\
\text { pain and fever. }\end{array}$ \\
\hline 15. & $\begin{array}{l}\text { Solanum nigrum } L . \\
\text { Solanaceae } \\
\text { Manathakkali }\end{array}$ & $\begin{array}{l}\text { Leaves and } \\
\text { tender } \\
\text { shoots }\end{array}$ & $\begin{array}{l}\text { Mouth ulcer and } \\
\text { cooling }\end{array}$ & $\begin{array}{l}\text { The boiled leaves ant tender } \\
\text { shoot to cure dropsy, the } \\
\text { fresh extract is used for the } \\
\text { treatment of cirrhosis of liver. }\end{array}$ \\
\hline 16. & $\begin{array}{l}\text { Solanum trilobatum } L \text {. } \\
\text { Solanaceae } \\
\text { Thudhuvelai }\end{array}$ & $\begin{array}{l}\text { Roots, } \\
\text { flowers and } \\
\text { fruits }\end{array}$ & $\begin{array}{l}\text { Nasobranchial } \\
\text { disease }\end{array}$ & $\begin{array}{l}\text { The leaf extraction is orally is } \\
\text { taken for nasobronchial } \\
\text { disease, }(25 \mathrm{~g} \text { per day for five } \\
\text { days. Root decoction and } \\
\text { powder of berries also used } \\
\text { for treatment for relive the } \\
\text { cough. }\end{array}$ \\
\hline 17. & $\begin{array}{l}\text { Solanum viarum } L \text {. } \\
\text { Solanaceae } \\
\text { Mullukathiri }\end{array}$ & $\begin{array}{l}\text { Roots and } \\
\text { fruits }\end{array}$ & $\begin{array}{l}\text { Respiratory } \\
\text { disease }\end{array}$ & $\begin{array}{l}\text { Fruits and roots used for the } \\
\text { respiratory and cardiac } \\
\text { disease. }\end{array}$ \\
\hline 18. & $\begin{array}{l}\text { Tribulus terrestris } L . \\
\text { Zygophyllaceae } \\
\text { Nerinjil }\end{array}$ & $\begin{array}{l}\text { Whole } \\
\text { plants }\end{array}$ & $\begin{array}{l}\text { fever, sterility and } \\
\text { skin disease }\end{array}$ & $\begin{array}{l}\text { Whole plant is used in the } \\
\text { treatment of fever, sterility } \\
\text { and skin disease. }\end{array}$ \\
\hline 19. & $\begin{array}{l}\text { Tylophora indica } L \text {. } \\
\text { Asclepidiaceae } \\
\text { Antamul }\end{array}$ & $\begin{array}{l}\text { Leaves and } \\
\text { roots }\end{array}$ & $\begin{array}{l}\text { Nasobranchial } \\
\text { disease }\end{array}$ & $\begin{array}{l}\text { Leaf paste is orally } \\
\text { administered } 10 \mathrm{~g} \text { per day for } \\
\text { one day to cure stomach } \\
\text { problems. The leaves and } \\
\text { roots are used to bronchial } \\
\text { asthma expectorant, } \\
\text { whooping cough, diarrhea } \\
\text { and dysentery. }\end{array}$ \\
\hline 20. & $\begin{array}{l}\text { Withania somnifera } L . \\
\text { Solanaceae } \\
\text { Amukura kilangu }\end{array}$ & $\begin{array}{l}\text { Leaves and } \\
\text { seeds }\end{array}$ & Stomach problem & $\begin{array}{l}\text { Leaf paste is orally } \\
\text { administered } 10 \mathrm{~g} \text { per day for } \\
\text { one day. Seed and leaves are } \\
\text { used to increase hardness of } \\
\text { mammary. }\end{array}$ \\
\hline
\end{tabular}

The 20 plant species of medicinal plants correspond to 18 genera and 12 families, and 17 species are recorded. In this study plant whole part (59\%) only, leaves (23\%) only, roots $(10 \%)$ only, and fruits $(9 \%)$ only are in tribal practicesThe families with high number of medicinal plant species is Solanaceae (6 species), followed by Ammaranthaceae ( 3 species), Aapocynaceae (2 species), Lamiaceae (2 species), Euphorbiaceae (3 species), and Nictaginaceae, Aristolochaceae, Zygophyllaceae, Asclipidiaceae (each families is one species).

Aerva lanata Linn. (Amaranthaceae)

The whole plants are used to the control of gall formation. The whole plant material is boiled with water, the decoction is applied for the 3-7 days or more the calcium salts formation is completely disappear. The leaf paste is directly applied for mechanical wounds/injuries. The root powder is used to pain and clean teath. 
Achyranthus aspera L. (Amaranthaceae)

The matured green leaves were collected and mixture with gingili oil and onion bulb roasted optimized condition, the leaves are controlled the rabies, the boiled leaves are consumed to relieve internal piles.

Andrographis panniculata Neex. (Acanthaceae)

Crushed leaves mixed in the warm water are administered for the treatment of malaria and cough. A handful of leaves are taken and an extract is made, mixed with milk, is taken internally to cure snake bites. Leaf paste is orally administered $10 \mathrm{~g}$ per day for one day. Seed and leaves are used to increase hardness of mammary.

Amaranthus spinosus L. (Amaranthaceae)

Plant paste mixed with deer musk is applied for the treatment of gout. Leaf paste is orally administered $10 \mathrm{~g}$ per day for one day. Seed and leaves are used to increase hardness of mammary.

Aristolochia indica L. (Aristolochiaceae)

The roots are macerated and applied to bitten area as treatment for snake bites. Dried root are powdered and about $10 \mathrm{~g}$ of powder is given with $100 \mathrm{ml}$ of human urine as the antidote for snake bites. Leaf paste is orally administered $10 \mathrm{~g}$ per day for one day. Seed and leaves are used to increase hardness of mammary.

Boerhavia diffusa L. (Nictaginaceae)

Whole plant decoction is taken. Fruits are consumed at flatulence, colic \&skin disease. The juice of plant is used for high blood pressure. For jaundice flowers are used. Leaves extract is also used to break stone from kidney and bladder. In powder form it is carminative.

Acalypha indica L. (Euphorbiaceae)

Root decoction is taken orally administered $100 \mathrm{~g}$ per day for one day used to dysentery. Leaves are used to cure the skin disease. Leaf fried in castor oil, is applied externally to get relieve from skin disease. Leaf paste is orally administered $10 \mathrm{~g}$ per day for one day. Seed and leaves are used to increase hardness of mammary.

Eclipta alba L. (Asteraceae)

The leaf extract is applied to relieve the dandruff and blacken gray hair. Leaf tincture mixed with gingelly oil is used for increase hair growth. Leaf paste is orally administered 10 g per day for one day. Seed and leaves are used to increase hardness of mammary.

Euphorbia hirta L. (Euphorbiaceae)

Whole plant is grind and mixed in water it is remedy to stop diarrhea. It is laxative, blood purifier and used to cure piles. Milky latex has ability to cure premature ejaculation. Measles are treated by Dhodhe.

Datura metal L. (Solanaceae)

Leaf paste is externally applied on the burn wound to cure skin. Few drops of leaf juice is poured into ear to treat earache Leaves and fruit are used for to treat asthma or wheezing like problems. Leaf paste is orally administered $10 \mathrm{~g}$ per day for one day. Seed and leaves are used to increase hardness of mammary.

Leucas aspera L. (Lamiaceae)

The vaporous from boiled leaves are inhaled to relieve cough and cold. Leaf paste is also applied external for 10 days as anti tumors. 
Ocimum sanctum L. (Lamiaceae)

Leaves juice is used in cold, fever and diabetes. Chewing tulsi leaves relieve cold and flu. Kidney stone can be removed if Tulsi leaves are taken regularly. Taking tulsi leaves along with the honey and water for six month remove stones through the urinary tract. It also strengthens the kidney. Leaf paste is orally administered $10 \mathrm{~g}$ per day for one day. Seed and leaves are used to increase hardness of mammary.

Phyllanthus niruri L. (Euphorbiaceae)

Root Decoction is taken orally administered (50 g) per day for scorpion sting day. Leaf paste is administered orally with milk twice a day for 10 days to cure jaundice. Leaf paste is orally administered $10 \mathrm{~g}$ per day for one day. Seed and leaves are used to increase hardness of mammary.

\section{Solanum nigrum L. (Solanaceae)}

The boiled leaves ant tender shoot to cure dropsy, the fresh extract is used for the treatment of cirrhosis of liver. Leaf juice is consumed orally twice a day for 10 days cure stomach ulcer. Taken as a food for whole plants to cure cough. Juice of the root extracted is used to asthma and whooping cough.

Solanum trilobatum L. (Solanaceae)

The leaf extraction is orally is taken for nasobronchial disease, $(25 \mathrm{~g}$ per day for five days. Root decoction and powder of berries also used for treatment for relive the cough. Leaf paste is orally administered $10 \mathrm{~g}$ per day for one day. Seed and leaves are used to increase hardness of mammary.

\section{Solanum viarum L. (Solanaceae)}

Fruits and roots used for the respiratory and cardiac disease. Leaf paste is orally administered $10 \mathrm{~g}$ per day for one day. Seed and leaves are used to increase hardness of mammary.

Tribulus terristris L. (Zygophillaceae)

Whole plant is used in the treatment of fever, sterility and skin disease.

Tylophora indica L. (Asclepidaceae )

Leaf paste is orally administered $10 \mathrm{~g}$ per day for one day to cure stomach problems. The leaves and roots are used to bronchial asthma expectorant, whooping cough, diarrhea and dysentery.

Withania somniferra L. (Solanaceae)

Leaf paste is orally administered $10 \mathrm{~g}$ per day for one day. Seed and leaves are used to increase hardness of mammary.

Solanum turvum L. (Solanaceae)

Relief from colds and Coughs. Powder mixed with hot water or cow milk and administrated orally to cure cracked foot Curing coughs externally applied on cracks. Powdered fried fruit is taken for cough to reduce body heat.

The present study deals with the traditional knowledge on 20 medicinal plants used by the kalrayans of the hill area for the treatment of various disease and disorders. The primary source of direct usage and discuss about the traditional species used and their application in medicinal use of the available indigenous species and traditional knowledge of the village people. To interpret the process of dissemination and diversification of herbal medicinal plants were found early identified from the study area. In practice it is vital way to find some 
useful information along with various communities and relation in traditional uses. The information may poor useful and lead to determination of new therapeutic compounds chemotheraphic relationship are based on the presence of some or similar chemical compounds in various taxa within a family. This form of correlation is observed when the following use of the known uses on the species in the same genus.

\section{CONCLUSIONS}

The present study deals with documenting traditional medicinal plants traditionally used by the tribal (kalrayans) of the Kalvarayan Hills. So, there is an urgent need for phytochemical and pharmacological screening of these plants to determine their original therapeutic values.

From this documentation of the medicinal plants is more important when ethnobotanical survey are to be undertaken to record information on wild plants, indigenous medicinal plants and entanged medicinal plants.

\section{References}

[1] Alcorn J. B., J Ethnobiol. 1(221) (1981) 230.

[2] Ayyanar M., Ignacimuthu S., Journal of ethnopharmacology 102 (2005) 246-225.

[3] Bhattee S. S., Beniwal B. S., Indian forester 2 (1988) 251.

[4] Dam D. P., Hajra P. K., Observation on ethnobotany of Monpas of kameng district, Arunachal Pradesh, In: Glimpses of Indian ethnobotany, edited by Jain SK, (Oxford \& IBH Publishing Co, New Delhi), 1981, 107- 114.

[5] Dhar U., Rawal R. S., Upreti J., J boil conserve 95 (2000) 57.

[6] Gadgil M., Curr. Sci. 70(1) (1996) 36.

[7] Gangwar A. K., Ramakirishnan P. S., Econ Bot. 44(1) (1990) 94.

[8] Haridasan K., Ethnobotanical studies in Arunachal Pradesh-A status report, proc National Seminar Traditional Knowledge base on herbal medicine and plant resources of north - east India: protection, utilization and conservation (National Institute of Science Communication and Information Resources, New Delhi), 2001, 154-167.

[9] Jain S. K., Mudgal V., A Hand Book of Ethnobotany, (Bishan Singh Mahindra pal Singh, Dehra Dun), 1999, 309.

[10] Jain S. K., Interdis Sci Rev. 11(3) (1986) 285.

[11] Khan Z. S., Khroo A. A., Dar G. H., Indian J traditional knowledge 3(4) (2004) 351.

[12] Mashelkar R. A., Employment News 26(50) (2002) 1.

[13] Rama Shankar, Rawat M. S., Medicinal plants and their potential in the economic development of Arunachal Pradesh, In: Arunachal Pradesh: Environmental Planning and Sustainable Development - Opportunities and Challenges (Himavikas Occasional publication, GB pant institute of Himalayan environment and development, kosi katarmal, Almora), No 16, 2002, 217-223. 
[14] Rama Shankar, Rawat M. S., Singh V. K., Bull Medico - Ethno - Bot Res 15(1-4) (1994) 36.

[15] Rama Shankar, Singh V. K., Rawat M. S., Bull medico - ethno - Bot Res 16(1-2) (1995) 36.

[16] Rawat M. S., Rama Shankar, Singh V. K., important medicinal plants of Arunachal Pradesh: collection and utilization (Himavikas Occasional Publication, GB Plant Institute of Himalayan Environment and Development, Kosi Katarmal Almora), No 11, 1998, 115-119.

[17] Sharma J. R., Mudgal V., Hajra P. K., Floristic Diversity-review, scope perspectives, In: Floristic conservation strategies in India, (BSI, Calcutta), 1997, 1-45. 